International Journal of Business Economics (IJBE)

Vol, 1 Issue 2, pp 102-116, March 2020

http://jurnal.umsu.ac.id/index.php/ijbe

eISSN 2686-472X

ORIGINAL ARTICLE

\title{
The Dynamics of Relations Between Systematic Risk, Fundamental Variables and Stock Prices in Pharmaceutical Companies
}

\author{
Sri Wahyuni Jamal
}

\begin{abstract}
This study aims to analyze systematic risk, earnings per share, price to earnings ratio, return on equity, and return on assets on stock prices in pharmaceutical companies listed on the Indonesia Stock Exchange. The method used in this research is quantitative method. Data collection techniques are carried out through secondary data that is data obtained indirectly by studying documents related to research. This study uses SPSS 22. Data analysis techniques with multiple linear regression. After conducting research with the hypothesis test found that partially the Return on Equity and Return on Assets variables significantly influence the stock price while the systematic risk variable, Earning per Share and Price Earning Ratio do not significantly influence the stock price. Then simultaneously using the $\mathrm{F}$ test, found systematic risk variables, Earning per Share, Price Earning Ratio, Return on Equity and Return on Assets simultaneously or simultaneously have a significant effect on stock prices on Pharmaceutical companies listed on the Indonesia Stock Exchange. This is a factor that should be considered by investors and companies alike, to pay more attention to the factors that contribute to the share price for the long-term sustainability of the company.
\end{abstract}

Keywords: : systematic risk, earnings per share, price to earnings ratio, return on equity, return on assets and stock prices

DOI : https://doi.org/ 10.30596/ijbe.v1i2.4438

JEL Classification: G00, G14

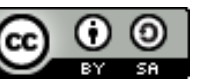

Published by International Journal of Business Economics (IJBE), Indonesia | Copyright (c) 2020 by the Author(s) | This is an open access article distributed under the Creative Commons Attribution License http://creativecommons.org/licenses/by/4.0), which permitsunrestricted use, distribution, and reproduction in any medium, provided the original work is properly cited.

Cite this article as:

Sri Wahyuni Jamal, S. W. (2020). The Dynamics Of Relations Between Systematic Risk, Fundamental Variables And Stock Prices in Pharmaceutical Companies. International Journal of Business Economics (IJBE), 1(2), 102-116.

Universitas Muhammadiyah Kalimantan Timur

Jl. Ir. H. Juanda No.15, Sidodadi, Samarinda, Kalimantan Timur, Indonesia

Corresponding Author: swj579@umkt.ac.id 


\section{International Journal of Business Economics (IJBE)}

Vol, 1 Issue 2, pp 102-116, March 2020

http:/ /jurnal.umsu.ac.id/index.php/ijbe

eISSN 2686-472X

\section{INTRODUCTION}

Pharmaceutical companies are certainly already familiar to us, especially to the people of Indonesia. The company is built to fulfil the community's needs of medicine. There have been many pharmacies established in all regions so that they are accessible to everyone.

But, whether the pharmaceutical companies listed on the Indonesia Stock Exchange are able to perform their financial performance well is the question. There are many investors who still doubt the performance of pharmaceutical companies in Indonesia because they do not know how the operational activities of the companies. The investor's doubts in investing as they consider the risks that might arise will affect the price on the stocks they have invested.

Therefore, investors should take into account some very important things in the investment decision making, such as how much the stock price is instilled, how much risk level is incurred and how much financial performance level (in the case of a fundamental variable) on the investment.

Risk will always be present in every investment, because investors must project how much revenue will be received during the investment period. The estimation of expected revenue is not necessarily the same as the real revenue due to certain factors that influence. If these factors can be predicted beforehand then it will be referred to as a risk. But, if the situation to be faced cannot be predicted beforehand, it is called uncertainty.

Basically, investors will always pay attention to the level of stock risk, in this case, stock risk that cannot be eliminated by diversification by investors is called systematic risk, symbolized as a determinant variable of expected stock returns, because high stock risk will provide a high rate of return, so that will also affect the price of the shares. Since a high stock risk will provide a high level of return, and vice versa, the lower the risk of a stock, it will provide a low rate of return as well. However, there are other variables that also affect the level of stock prices, called fundamental variables such as EPS, PER, ROA and ROE.

The development of pharmaceutical companies in Indonesia has a positive impact on Indonesian people. With the development of pharmaceutical companies, people's needs of medicines will be fulfilled. Indonesian do not have to go out of Indonesia to find medicine and it also can reduce the cost. However, along with the development of this pharmaceutical company, research needs to be done on how the fundamental factors affect the price of stocks in pharmaceutical companies. Then, what strategies to be done by the company to improve its performance in the field of pharmacy can be estimated, especially its financial performance.

As research conducted by (Angela, 2018), with the title "The Analysis of Stock Price in Tourism Industry Listed in Indonesia Stock Exchange 2012-2016", the results show that from 5 independent variables, DER had negative significant to the stock price, CR had negative significant to the price, EPS positive significant to the stock price, PBV positive significant to the stock price and ROA negative significant to the stock price. DER, CR, EPS, PBV and ROA simultaneously had a significant relationship to the stock price.

In the research conducted by (Sulistyowati, 2011), with the title "The influence of earning per share (EPS), price earning ratio (PER) and dividend payout ratio (DPR) on the price of shares (empirical study of the Food \& Beverages companies listed In IDX), indicating that partially and simultaneously, EPS, PER and DPR variables have significant effect on the stock price.

In a study on the effect of fundamental variables on the stock prices of public companies in the Indonesian stock exchange conducted by (Pasaribu \& Gunadarma, 2008), it 


\section{International Journal of Business Economics (IJBE)}

Vol, 1 Issue 2, pp 102-116, March 2020

http://jurnal.umsu.ac.id/index.php/ijbe

eISSN 2686-472X

shows simultaneous and partial results that growth variable, profitability of leverage position, liquidity and efficiency of the company significantly affects the share price.

In the research conducted by (Hatta \& Dwiyanto, 2012), with the title "The Company Fundamental Factors and Systematic Risk In Increasing Stock Price", the results of estimation stock prices, it is discovered that EPS, PER and HSM variables have positive and significant effects to stock prices, while DER and NPM variables have negative and significant effects.

Tamuntuan, (2015), with the title "Analysing the Effect of Return on Equity, Return on Assets and Earnings per share toward share price:an empirical study of food and beverage companies listed on Indonesia Stock Exchange" tests conducted show that ROE, ROA and EPS simultaneously have significant effect toward the share price, yet partially only EPS does significantly affect the share price, both ROE and ROA don't have significant effect to the share price. Talamati \& Pangemanan, (2014) with the title "The Effect of Earnings per Share (EPS) \& Return on Equity (ROE) on Stock Price of Banking Company Listed in Indonesia Stock Exchange (IDX) 2010-2014”, tests conducted show aimultaneously both EPS and ROE variables affect stock price. Partially, EPS have significant positive effect on Stock Price while ROE does not affect partially on Stock Price. Mogonta \& Pandowo, (2016) the title "Analyzing the Effect Return on Assets, Return on Equity and Earning Per Share on Market Share Price: A Study of LQ-45 Mining Companies Listed on Indonesia Stock Exchange" the results of partially, ROA has positive significant effect on market share price, ROE has negative effect on market share price and EPS not have significant effect on market share price. Issah \& Ngmenipuo, (2015) the title "An Empirical Study Of The Relationship Between Profitability Rations and Market Share Prices of Publicly Traded Banking Financial Institutions in Ghana" these findings a significant linear relationship between the ROA, ROE and ROI together the market prices per share, with the ROE contributing more than the ROA. Kabajeh, et al., (2012) the title "The Relationship between the ROA, ROE and ROI Ratios with Jordanian Insurance Public Companies Market Share Prices" the results also showed a positive but low relationship between each of ROA ratio separately and ROI ratio separately with Jordanian insurance public companies share prices.Anwaar, (2016) "Impact of Firms' Performance on Stock Returns (Evidence from Listed Companies of FTSE-100 Index London, UK)" results shows that net profit margin, return on assets has got significant positive impact on stock returns while earnings per share has got significant negative impact on stock returns. "The Effect of Earnings Per Share Categories on Share Price Behaviour: Some South African Evidence" by Robbetze, Villiers, \& Harmse, (2017), results shows that basic EPS correlated best with the changing behavior of share prices.

"Fundamental Determinants affecting Equity Share Prices on BSE-200 Companies in India" by Sukhija, (2014), it can be concluded that Earning Per Share is emerged as significant determinant with the positive sign in three years out of seven years while Dividend Per Share is significantly negative in two years. Book Value Per Sharehas influenced the market price of share significantly in five out of seven years. Price Earning Ratio has emerged a significant positive determinant in two years out of seven years. Dividend Payout Ratio has emerged as significant determinant of market price of share with the negative sign in two out of the seven years of study.

Menaje, (2012) the title "Impact of Selected Financial Variables on Share Price of Publicly Listed Firns in the Philippines", result of the Spearman Rank order Correlation 


\section{International Journal of Business Economics (IJBE)}

Vol, 1 Issue 2, pp 102-116, March 2020

http://jurnal.umsu.ac.id/index.php/ijbe

eISSN 2686-472X

disclosed strong positive correlation of EPS with share price. ROA disclosed a weak negative correlation with share price.

"Corporate Attribute and Share Value Of Listed Pharmaceutical Firms In Nigeria" by Abba \& Suleiman, (2016), the study reveals that firm size, leverage, profitability and growth have positive and significant relationship with share price implying that they have impact in increasing share price.

Koluku, Pet al., (2015), “Analysis Of Market Risk, Financial Leverage and Firm Size Toward Stock Return On Non-Banking Companies Listed in LQ45 Index of IDX", the results showed firm size and market risk have significant effect on stock return, while financial leverage has no significant effect on stock return. Kumar, (2017) "Impact Of Earning per Share and Price Earning Ratio on Market Price of Share: A Study on Auto Sector in India" the result of the study concludes that earning per share has found to be a very strong forecaster of market price of share, while price earnings ratio impact significantly on the prediction of market price of share of select companies of auto sector as whole. Musyoki, (2012) "Changes in Share Prices as a Predictor of Acoounting Earning for financial firms listed in Nairobi Securities Exchange" the result Eleven companies were analyzed and all ofthem had positive change towards the accounting earnings in relation to the share price. Additionally,the relationship between accounting variables and the Nairobi Stock Exchange information indicated mixed results, with some companies showing a strong positive correlation and others weak correlation.

Inyiama, (2015) with the title "Does Earning per Share Determine Market Price of Ordinary Shares? Evidence From Nigeria Banking Sector (2000-2013)", the implication of the findings is that an increase in earnings has the tendency of increasing significantly the market price of shares and earnings per share is one of the key factors responsible for fluctuations in market price of ordinary shares in Nigerian banking sector. Vora, (2018), "Influence of Financial Performance Indicators on Market Price of Shares of Nifty 50 Companies" that result of the Pearson's Correlation revealed a very strong and positive correlation of EPS and market share price. ROA, ROI and ROE unveiled a weak correlation with market share price.

However, as indicated above several studies have also identified other factors which are not only covered by fundamental variables and have a strong relationship with stock prices. In this case, this study combines not only the components of fundamental variables but also systematic risks in addition to what was considered important by previous studies.

\section{METHODS}

This study analyzed the price of shares in pharmaceutical companies listed on the Indonesia Stock Exchange during the 2013-2017 period. This type of research is a quantitative approach to examine the effect of systematic risk, EPS, PER, ROA and ROE on the stock prices of pharmaceutical companies listed on the Indonesia Stock Exchange.

The population in this study were 10 pharmaceutical companies listed on the Indonesia Stock Exchange.

Table 1. Population of Pharmaceutical Companies

\begin{tabular}{ccl}
\hline NO & STOCK CODE & \multicolumn{1}{c}{ COMPANY } \\
\hline 1 & DVLA & Darya Varia Laboratoria Tbk \\
2 & INAF & Indofarma (Persero) Tbk \\
3 & KAEF & Kimia Farma (Persero) Tbk \\
\hline
\end{tabular}




\section{International Journal of Business Economics (IJBE)}

Vol, 1 Issue 2, pp 102-116, March 2020

http://jurnal.umsu.ac.id/index.php/ijbe

eISSN 2686-472X

\begin{tabular}{ccl}
\hline NO & STOCK CODE & \multicolumn{1}{c}{ COMPANY } \\
\hline 4 & KLBF & Kalbe Farma Tbk \\
5 & MERK & Merck Indonesia Tbk \\
6 & PYFA & Pyridam Farma Tbk \\
7 & SCPI & Merck Sharp Dohme Pharma Tbk \\
8 & SIDO & Industri Jamu \& Farmasi Sido Muncul Tbk \\
9 & SQBB & Taisho Pharmaceutical Indonesia Tbk \\
10 & TSPC & Tempo Scan Pasific Tbk \\
\hline
\end{tabular}

Source: $w w w . i d x . c o . i d(2019)$

For the sample, itwas using probability sampling technique to choose 6 companies with several criteria as follows:

1. Pharmaceutical companies listed on the Indonesia Stock Exchange during the 20132017 period.

2. The financial statements used were limited to the financial statements of pharmaceutical companies which were uploaded on the official website of the Indonesia Stock Exchange for the period 2013-2017.

3. Pharmaceutical companies that had the highest share price in the 2013-2017 period.

4. Companies that sell products that are already well known and familiar among the Indonesian people.

Table 2. Sample of Pharmaceutical Companies

\begin{tabular}{ccl}
\hline NO & STOCK CODE & \multicolumn{1}{c}{ COMPANY } \\
\hline 1 & DVLA & Darya Varia Laboratoria Tbk \\
2 & INAF & Indofarma (Persero) Tbk \\
3 & KAEF & Kimia Farma (Persero) Tbk \\
4 & KLBF & Kalbe Farma Tbk \\
5 & MERK & Merck Indonesia Tbk \\
6 & TSPC & Tempo Scan Pasific Tbk \\
\hline
\end{tabular}

Source: www.idx.co.id (2019)

The data used in this study was a secondary data. Secondary data is data obtained by people who conduct research from existing sources. In this study, the data was derived from the official website of Indonesia Stock Exchange: www.idx.co.id. Data collection technique used in this study was documentation, in which documentation is the collection of data obtained from existing documents or records that are stored, whether in the form of transcript notes, books, newspapers and so forth. This study aims to look at the effect of systematic risk, EPS, PER, ROA and ROE on stock prices. For this reason, data analysis techniques are used as follows: Multiple Linear Regression. With the formula:

$\mathrm{Y}=\alpha+\beta 1 \mathrm{X} 1+\beta 2 \mathrm{X} 2+\beta 3 \mathrm{X} 3+\beta 4 \mathrm{X} 4+\beta 5 \mathrm{X} 5 \mathrm{e}$

Description:

$\mathrm{Y}$ : Stock Price; $\alpha$ : Constant; $\beta$ : Regression Coefficient; $\mathrm{X}_{1}$ : Systematic Risk; $\mathrm{X}_{2}$ : EPS; $\mathrm{X}_{3}$ : PER; $\mathrm{X}_{4}$ : ROE; $\mathrm{X}_{5}: \mathrm{ROA}$; e: Error Standard

\section{Classical Assumption Test}




\section{International Journal of Business Economics (IJBE)}

Vol, 1 Issue 2, pp 102-116, March 2020

http:/ /jurnal.umsu.ac.id/index.php/ijbe

eISSN 2686-472X

This is a requirement in parametric analysis in which the distribution of data must be normal. For the test, the Kolmogorof-Smirnov One Sample test is used to determine whether the data distribution for each variable is normal or not. To detect the presence or absence of multicollinearity by looking at the tolerance and VIF value. The smaller the tolerance valueis, the greater the VIF will be, the higher the multicollinearity problem will occur. Most studies mentioned that if tolerance is more than 0.1 and VIF is less than 10 then multicollinearity does not occur. To recognize the presence or absence of heteroscedasticity by looking at the pattern of points in scatterplots regression. If the points spread with unclear patterns above and below the number 0 on the $\mathrm{Y}$ axis then there is no heteroscedasticity problem.

To find the presence or absence of autocorrelation the Durbin-Watson test is performed with the rule if the value of $\mathrm{dL}<\mathrm{DW}>\mathrm{dU}$ and $\mathrm{dL}<(4-\mathrm{DW})>\mathrm{dU}$ that means autocorrelation do not occur.

$T$ test, used to determine the effect of partially independent variables on the dependent variable, whether the effect is significant or not. If a probability of $>0.05$ is obtained, it can be said that the independent variable has no effect on the dependent variable and if a probability of $<0.05$ is obtained, the independent variable significantly influences the dependent variable. F test or commonly called the Simultaneous Regression Coefficient Test, which is to find out the independent variables simultaneously against the independent variables, whether the effect is significant or not. If a probability of $>0.05$ is obtained, it can be said that the independent variable has no effect on the dependent variable and if a probability of $<0.05$ is obtained, the independent variable significantly influences the dependent variable. Coefficient of determination $\left(\mathrm{R}^{2}\right)$, to find out how much the ability of the independent variable to explain the dependent variable.

\section{RESULT AND DISCUSSION}

The research data used are as follows:

1. Systematic Risk is a market risk that is general and applies to all shares in the capital market. The formula is as follows:

$$
\beta=\frac{N \sum R m \cdot R i-\left(\sum R m\right)\left(\sum R i\right)}{N \sum R m^{2}-\left(\sum R m\right)^{2}}
$$

Description:

$$
\begin{aligned}
& R m=\text { Market Return } \\
& R i=\text { Stock Return } \\
& N=\text { Total of Data } \\
& B=\text { Stock Beta }
\end{aligned}
$$

Table 3. Systematic Risk of Pharmaceutical Companies

\begin{tabular}{ccccccc}
\hline No & $\begin{array}{c}\text { Stock } \\
\text { Code }\end{array}$ & $\mathbf{2 0 1 3}$ & $\mathbf{2 0 1 4}$ & $\mathbf{2 0 1 5}$ & $\mathbf{2 0 1 6}$ & $\mathbf{2 0 1 7}$ \\
\hline 1 & DVLA & $-8,7350$ & $-1,0019$ & 1,8620 & 2,2844 & 0,4993 \\
2 & SIDO & $-14,9112$ & $-0,5557$ & 0,7936 & $-0,3560$ & 0,2055 \\
3 & KAEF & 5,8673 & 6,4098 & 3,2771 & 14,1041 & $-0,0777$ \\
4 & KLBF & $-5,1883$ & 2,0054 & 2,2487 & 0,9642 & 0,4938 \\
5 & MERK & $-7,0459$ & $-0,6632$ & 1,2355 & 2,3362 & $-0,3253$ \\
6 & TSPC & 3,6951 & $-0,4498$ & 2,9434 & 0,8205 & $-0,3689$ \\
\hline \multicolumn{7}{l}{ Source: secondary data, www.idx.co.id from 2013-2017,data was processed in 2019) }
\end{tabular}




\section{International Journal of Business Economics (IJBE)}

Vol, 1 Issue 2, pp 102-116, March 2020

http://jurnal.umsu.ac.id/index.php/ijbe

eISSN 2686-472X

2. Earning Per Share (EPS), a ratio that describes the portion of earnings for each share obtained by investors. With the following formula:

Earning per Share $(E P S)=\frac{(\text { Net Income }- \text { Dividend })}{\text { Outstanding share }}$

Tabel 4. Earning Per Share (EPS) of Pharmaceutical Companies

\begin{tabular}{ccccccc}
\hline No & $\begin{array}{c}\text { Stock } \\
\text { Code }\end{array}$ & $\mathbf{2 0 1 3}$ & $\mathbf{2 0 1 4}$ & $\begin{array}{c}\text { Period } \\
\mathbf{2 0 1 5}\end{array}$ & $\mathbf{2 0 1 6}$ & $\mathbf{2 0 1 7}$ \\
\hline 1 & DVLA & 149 & 72.26 & 96.33 & 135.79 & 144.87 \\
2 & SIDO & 27.06 & 27.68 & 29.17 & 32.04 & 35.59 \\
3 & KAEF & 38.63 & 42.24 & 44.81 & 48.15 & 58.84 \\
4 & KLBF & 41 & 44.08 & 42.76 & 49.06 & 51.28 \\
5 & MERK & 1264 & 8101.44 & 6363.64 & 343.4 & 328.99 \\
6 & TSPC & 141 & 128.75 & 155.99 & 119.17 & 120.85 \\
\hline
\end{tabular}

(Source: secondary data, www.idx.co.id from 2013-2017,data was processed in 2019)

3. Price Earning Ratio (PER) shows the amount of money that investors are willing to pay for each dollar of reported profit. The formula is as follows:

$$
\text { PER }=\frac{P}{E P S}
$$

Table 5. Price Earning Ratio (PER) of Pharmaceutical Companies

\begin{tabular}{|c|c|c|c|c|c|c|}
\hline No & $\begin{array}{l}\text { Stock } \\
\text { Code }\end{array}$ & 2013 & 2014 & $\begin{array}{r}\text { Period } \\
2015\end{array}$ & 2016 & 2017 \\
\hline 1 & DVLA & 14,77 & 23,39 & 13,50 & 12,92 & 13,53 \\
\hline 2 & SIDO & 25,87 & 22,04 & 18,85 & 16,23 & 15,31 \\
\hline 3 & KAEF & 15,27 & 34,68 & 19,42 & 57,11 & 45,89 \\
\hline 4 & KLBF & 30,49 & 41,52 & 30,87 & 30,88 & 32,96 \\
\hline 5 & MERK & 8,88 & 0,99 & 1,06 & 26,79 & 25,84 \\
\hline 6 & TSPC & 21,81 & 21,40 & 11,22 & 16,43 & 14,89 \\
\hline
\end{tabular}

(Source: secondary data, www.idx.co.id from 2013-2017,data was processed in 2019)

4. Return on Equity (ROE), to measure how much profit or profit belongs to the owner of his own capital. The formula is as follows:

$$
\mathrm{ROE}=\frac{\text { Net Income EBIT }}{\text { Total assets }}
$$

Table 6. Return On Equity (ROE) of Pharmaceutical Companies

\begin{tabular}{ccccccc}
\hline No & Stock Code & $\mathbf{2 0 1 3}$ & $\mathbf{2 0 1 4}$ & $\mathbf{2 0 1 5}$ & $\mathbf{2 0 1 6}$ & $\mathbf{2 0 1 7}$ \\
\hline 1 & DVLA & 13,75 & 8,41 & 11,08 & 14,09 & 14,53 \\
2 & SIDO & 15,46 & 15,76 & 16,84 & 17,42 & 18,43 \\
3 & KAEF & 13,28 & 13,06 & 13,59 & 11,96 & 12,89 \\
4 & KLBF & 23,18 & 21,74 & 18,81 & 18,86 & 17,66 \\
5 & MERK & 34,25 & 32,78 & 30,10 & 26,40 & 23,95 \\
6 & TSPC & 11,81 & 14,14 & 12,20 & 11,77 & 10,97 \\
\hline \multicolumn{2}{l}{ (Source: secondary data, www.idx.co.id from 2013-2017,data was processed in 2019) }
\end{tabular}




\section{International Journal of Business Economics (IJBE)}

Vol, 1 Issue 2, pp 102-116, March 2020

http://jurnal.umsu.ac.id/index.php/ijbe

eISSN 2686-472X

5. Return On Assets (ROA), this measurement tool is used to compare profits after tax with total assets. The formula is as follows:

$$
\text { ROA }=\frac{\text { Net Income after Tax }}{\text { Total assets }}
$$

Table 7. Return on Assets (ROA) of Pharmaceutical Companies

\begin{tabular}{ccccccc}
\hline No & $\begin{array}{c}\text { Stock } \\
\text { Code }\end{array}$ & $\mathbf{2 0 1 3}$ & $\mathbf{2 0 1 4}$ & $\mathbf{2 0 1 5}$ & $\mathbf{2 0 1 6}$ & $\mathbf{2 0 1 7}$ \\
\hline 1 & DVLA & 19.43 & 18.93 & 32.81 & 6.36 & 37.14 \\
2 & SIDO & 5.24 & 4.19 & 3.83 & 36.28 & 6.35 \\
3 & KAEF & 24.16 & 12.63 & 20.27 & 11.13 & 6.56 \\
4 & KLBF & 18.05 & 24.67 & 21.32 & 18.09 & 17.12 \\
5 & MERK & 60.66 & 27.32 & 16.10 & 39.61 & 17.54 \\
6 & TSPC & 36.60 & 18.15 & 29.72 & 22.61 & 33.59 \\
\hline Source: secondary data, www.idx.co.id from 2013-2017,data was processed in 2019)
\end{tabular}

6. Stock Price

Table 8. Stock Price of Pharmaceutical Companies

\begin{tabular}{ccccccc}
\hline No & \multirow{2}{*}{ Stock Code } & $\mathbf{2 0 1 3}$ & $\mathbf{2 0 1 4}$ & $\begin{array}{c}\text { Period } \\
\mathbf{2 0 1 5}\end{array}$ & $\mathbf{2 0 1 6}$ & $\mathbf{2 0 1 7}$ \\
\hline 1 & DVLA & 2200 & 1690 & 1300 & 1755 & 1960 \\
2 & SIDO & 700 & 610 & 550 & 520 & 545 \\
3 & KAEF & 590 & 1465 & 870 & 2750 & 2700 \\
4 & KLBF & 1250 & 1830 & 1320 & 1515 & 1690 \\
5 & MERK & 9450 & 8000 & 6775 & 9200 & 8500 \\
6 & TSPC & 3075 & 2755 & 1750 & 1970 & 1800 \\
\hline
\end{tabular}

(Source: secondary data, www.idx.co.id from 2013-2017,data was processed in 2019)

Data Analysis and Hypothesis Test

Multiple Linear Regression Analysis

By using SPSS, we get the following results from multiple linear regression:

Table 9. The Result of Multiple Linear Regression Analysis Coefficients $^{\mathrm{a}}$

\begin{tabular}{|c|c|c|c|c|c|}
\hline \multirow[b]{2}{*}{ Model } & \multicolumn{2}{|c|}{ Unstandardized Coefficients } & $\begin{array}{l}\text { Standardized } \\
\text { Coefficients }\end{array}$ & \multirow[b]{2}{*}{$\mathrm{t}$} & \multirow[b]{2}{*}{ Sig. } \\
\hline & $\mathrm{B}$ & Std. Error & Beta & & \\
\hline 1 (Constant) & -3579.713 & 1343.683 & & -2.664 & .014 \\
\hline Systematic Risk & 22.821 & 75.523 & .042 & .302 & .765 \\
\hline Earning Per Share & .364 & .288 & .246 & 1.263 & .219 \\
\hline Price Earning Ratio & 32.543 & 36.088 & .149 & .902 & .376 \\
\hline Return On Equity & 223.927 & 74.974 & .547 & 2.987 & .006 \\
\hline Return On Assets & 67.544 & 29.629 & .321 & 2.280 & .032 \\
\hline
\end{tabular}

a. Dependent Variable: Stock Price

Then the equation for this analysis is obtained:

$$
Y=-3579,713+22,821 X_{1}+0,364 X_{2}+32,543 X_{3}+232,927 X_{4}+67,544 X_{5}
$$




\section{International Journal of Business Economics (IJBE)}

Vol, 1 Issue 2, pp 102-116, March 2020

http://jurnal.umsu.ac.id/index.php/ijbe

eISSN 2686-472X

1) Constant $b_{0}=-3579,713$, which means that if Systematic Risk (X1), Earning Per Share (X2), Price Earning Ratio (X3), Return on Equity (X4) and Return on Assets (X5) are 0, then the stock price value is negative as much as 3579.713

2) Coefficient $b_{1}=22.821$, which means that if Earning Per Share, Price Earning Ratio, Return on Equity and Return on Assets are fixed, Systematic Risk is increased by 1 unit, then the share price will increase by 22.821 .

3) Coefficient $b_{2}=0.364$, which means that if Systematic Risk, Price Earning Ratio, Return on Equity and Return on Assets are fixed, Earning Per Share is increased by 1 unit, then the stock price will increase by 0.364 .

4) Coefficient $b_{3}=32.543$, which means that if Systematic Risk, Earning Per Share, Return on Equity and Return on Assets variables are fixed, the Price Earning Ratio is increased by 1 unit, then the stock price will increase by 35.543 .

5) Coefficient $b_{4}=232.927$, which means that the Systematic Risk, Earning Per Share, Price Earning Ratio, and Return on Assets are fixed, Return on Equity is increased by 1 unit, then the share price will increase by 232,927

6) Coefficient $b_{5}=67.544$, which means that if the Systematic Risk variable, Earning Per Share, Price Earning Ratio and Return on Equity are fixed, Return on Assets is increased by 1 unit, then the stock price will increase by 67.544 .

\section{Classical Assumption Test}

Normality Test

This study used SPSS by looking at the results of the One-Sample KolmogorovSmirnov Test. Here is the result:

Table 10.The Result of Normality Test One-Sample Kolmogorov-Smirnov Test

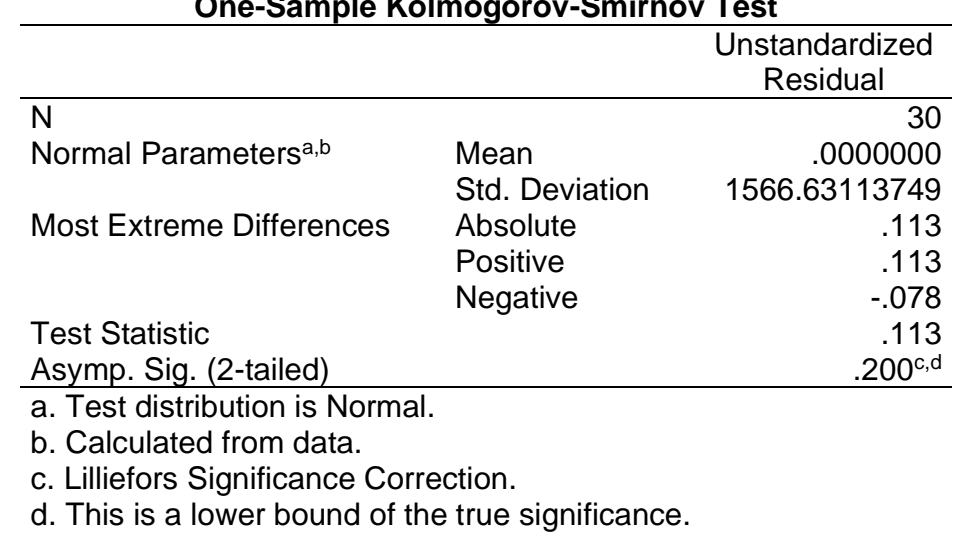

After analyzing the data through the Kolmogorov-Smirnov One Sample Test, the result is 0.113 and the significance value is 0.200 . With these results, it can be said that all data used are normally distributed, because the significance value is higher than $\alpha(\alpha=0.05)$, which is $0.200>0.05$

This test was carried out to find out whether there is a linear relationship between the independent variables that do not have a perfect relationship or contain multicollinearity. By using SPSS 22, the following is the result: 


\section{International Journal of Business Economics (IJBE)}

Vol, 1 Issue 2, pp 102-116, March 2020

http://jurnal.umsu.ac.id/index.php/ijbe

eISSN 2686-472X

Table 11. The Result of Multicollinearity Test

\begin{tabular}{ccc}
\hline Model & \multicolumn{2}{c}{ Collinearity Statistics } \\
& Tolerance & VIF \\
\hline (Constant) & & \\
Systematic Risk &, 735 & 1,361 \\
Earning Per Share &, 368 & 2,718 \\
Price Earning Ratio &, 515 & 1,940 \\
Return on Equity &, 417 & 2,398 \\
Return on Assets &, 704 & 1,421 \\
\hline
\end{tabular}

From the result of this test, it can be seen that the (5) five independent variables have a Tolerance Value such as, Systematic Risk $\left(\mathrm{X}_{1}\right)$ is 0.735, Earning Per Share $\left(\mathrm{X}_{2}\right)$ is 0.368 , Price Earning Ratio $\left(\mathrm{X}_{3}\right)$ is 0.515 , Return on Equity $\left(\mathrm{X}_{4}\right)$ is 0.417 and Return on Assets $\left(\mathrm{X}_{5}\right)$ is 0.704 . From these data, all of the independent variable have a tolerance value $>0.1$ and a VIF value $<10$, so it can be concluded that there are no signs of multicollinearity.

Similar to the normality test and multicollinearity test, the heteroscedasticity test also uses SPSS 22. Here is the result:

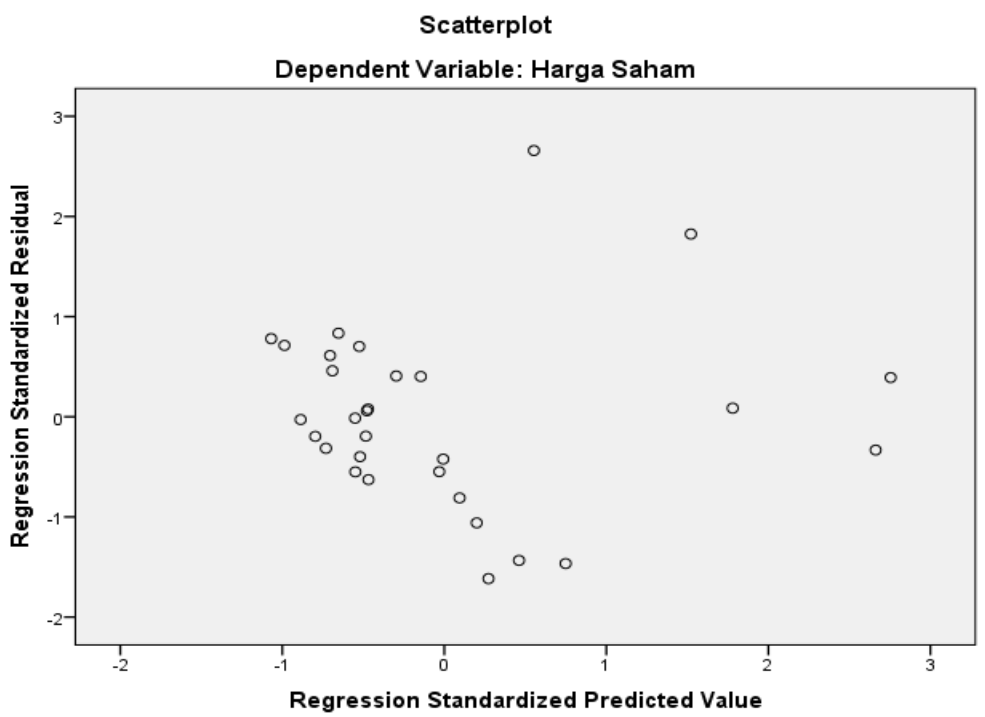

Figure 1.The Result of Heteroscedasticity Test

It can be seen on Figure 1, the data points are found scattered in the lower and upper regions of the number 0 and the points do not make a particular pattern. Hence, the regression model that was formed and the researcher concluded that the heteroscedasticity does not occur.

this is the result of autocorrelation test:

Table 12.The Result of Autocorrelation Test Model Summary ${ }^{b}$

\begin{tabular}{lccccc}
\hline Model & $\mathrm{R}$ & $\mathrm{R}$ Square & $\begin{array}{c}\text { Adjusted R } \\
\text { Square }\end{array}$ & $\begin{array}{c}\text { Std. Error of the } \\
\text { Estimate }\end{array}$ & Durbin-Watson \\
\hline 1 & $.815^{\mathrm{a}}$ & .664 & .595 & 1722.107 & 2.280 \\
\hline a. Predictors: (Constant), Systematic Risk, Earning Per Share, Price Earning Ratio, Return \\
On Equity, Return on Assets \\
b. Dependent Variable: Stock Price
\end{tabular}




\section{International Journal of Business Economics (IJBE)}

Vol, 1 Issue 2, pp 102-116, March 2020

http:/ /jurnal.umsu.ac.id/index.php/ijbe

eISSN 2686-472X

Based on these test results, it is found that the DW value is 2.280 in which $\mathrm{dL}<\mathrm{DW}>$ $\mathrm{dU}$ or $1.0706<2.280>1.8326$. $\mathrm{dL}$ and $\mathrm{dU}$ are obtained from the Durbin-Watson table with $\mathrm{n}$ $=30$ and $\mathrm{k}=5$. So it can be said that autocorrelation in multiple linear regression does not occur.

To test the hypothesis in this study, the researcher was using two methods, partially by t-test and simultaneously by applying the F-test. The t-test is used to determine the partial effect between independent variables on the dependent variable. Here is the result:

Table 14. The Result of t-test

Coefficients $^{\mathrm{a}}$

\begin{tabular}{|c|c|c|c|c|c|c|c|c|}
\hline \multirow{2}{*}{\multicolumn{2}{|c|}{ Model }} & \multicolumn{2}{|c|}{$\begin{array}{l}\text { Unstandardized } \\
\text { Coefficients }\end{array}$} & \multirow{2}{*}{$\begin{array}{c}\text { Standardized } \\
\text { Coefficients } \\
\text { Beta }\end{array}$} & \multirow[b]{2}{*}{$\mathrm{T}$} & \multirow[b]{2}{*}{ Sig. } & \multicolumn{2}{|c|}{ Collinearity Statistics } \\
\hline & & $\mathrm{B}$ & Std. Error & & & & Tolerance & VIF \\
\hline 1 & (Constant) & -3579.713 & 1343.683 & & -2.664 & .014 & & \\
\hline & Systematic Risk & 22.821 & 75.523 & .042 & .302 & .765 & .735 & 1.361 \\
\hline & Earning Per Share & .364 & .288 & .246 & 1.263 & .219 & .368 & 2.718 \\
\hline & Price Earning Ratio & 32.543 & 36.088 & .149 & .902 & .376 & .515 & 1.940 \\
\hline & Return On Equity & 223.927 & 74.974 & .547 & 2.987 & .006 & .417 & 2.398 \\
\hline & Return On Assets & 67.544 & 29.629 & .321 & 2.280 & .032 & .704 & 1.421 \\
\hline
\end{tabular}

From these results, it can be concluded that:

1) Partial test between the independent variable Systematic Risk $\left(X_{1}\right)$ and the stock price (Y) with a significance value of 0.765 . Because the significance value is $0.765>0.05$, it can be said that systematic risk partially has no significant effect on stock prices.

2) Partial test between the independent variable Earning Per Share $\left(\mathrm{X}_{2}\right)$ and the stock price (Y) with a significance value of 0.219 . Because the significance value is $0.219>0.05$, it means that Earning Per Share partially has no significant effect on stock prices.

3) Partial test between the independent variable Price Earning Ratio $\left(\mathrm{X}_{3}\right)$ and stock price (Y) with a significance value of 0.376 . Because the significance value is $0.376>0.05$, it means that Price Earning Ratio partially has no significant effect on stock prices.

4) Partial test between the independent variable Return on Equity $\left(\mathrm{X}_{4}\right)$ and the stock price (Y) with a significance value of 0.006 . Because the significance value is $0.006<0.05$, it can be concluded that Return on Equity partially has a significant effect on stock prices.

5) Partial test between the independent variable Return on Assets $\left(\mathrm{X}_{5}\right)$ and stock prices (Y) with a significance value of 0.032 . Because the significance value of $0.032<0.05$ which means that Return on Assets partially has a significant effect on stock prices.

the following table is the result of simultaneous :

Table 15. Uji F

ANOVA $^{\mathrm{a}}$

\begin{tabular}{|c|c|c|c|c|c|c|}
\hline Model & & $\begin{array}{l}\text { Sum of } \\
\text { Squares }\end{array}$ & $\mathrm{Df}$ & Mean Square & $\mathrm{F}$ & Sig. \\
\hline \multirow[t]{3}{*}{1} & Regression & 140935873.659 & 5 & 28187174.732 & 9.505 & $.000^{b}$ \\
\hline & Residual & 71175660.508 & 24 & 2965652.521 & & \\
\hline & Total & 212111534.167 & 29 & & & \\
\hline
\end{tabular}

a. Dependent Variable: Stock Price

b. Predictors: (Constant), Systematic Risk, Earning Per Share, Price Earning Ratio, Return On Equity, Return On Assets 


\section{International Journal of Business Economics (IJBE)}

Vol, 1 Issue 2, pp 102-116, March 2020

http:/ /jurnal.umsu.ac.id/index.php/ijbe

eISSN 2686-472X

It can be seen clearly from F-test result that the significant value is0.000, in which if the significant value $0.000<0.05$ that means Systematic Risk, Earning per Share, Price Earning Ratio, Return on Equity and Return on Assets simultaneously have significant effect on stock price.

The following table is the result of Determination Coefficient calculated by using SPSS 22:

Table16. Coefficient of Determination

Model Summaryb

\begin{tabular}{lccccr}
\hline Model & $\mathrm{R}$ & $\mathrm{R}$ Square & $\begin{array}{c}\text { Adjusted R } \\
\text { Square }\end{array}$ & $\begin{array}{c}\text { Std. Error of the } \\
\text { Estimate }\end{array}$ & Durbin-Watson \\
\hline 1 & $.815^{\mathrm{a}}$ & .664 & .595 & 1722.107 & 2.280 \\
\hline a. Predictors: (Constant), Systematic Risk, Earning Per Share, Price Earning Ratio, Return \\
On Equity, Return On Assets \\
b. Dependent Variable: Stock Price
\end{tabular}

It can be concluded based on the table that the coefficient of determination (R2) is 0.595 or $59.5 \%$. This means that systematic risk, earnings per share, price earning ratio, return on equity and return on assets simultaneously influence the stock price by $59.5 \%$ while the remaining $40.5 \%$ is influenced by other variables outside of the scope of this study.

\section{DISCUSSION}

This study found $59.5 \%$ of the dependent variable stock price explained by the independent variable systematic risk, earnings per share, price earning ratio, return on equity and return on assets. The remaining $40.5 \%$ is influenced by other variables outside of the scope of this study.

$\mathrm{H} 1:$ Partially, systematic risk does not significantly affect stock prices. This is because systematic risk is a general risk that always exists and cannot be eliminated by diversification. Hence, any systematic risk situation will not affect the stock price. The results of this study are also in accordance with the results of (Darmayanti, 2015) which states that there is no significant effect between the systematic risk of the stock price. So is the same with research of (Hatta \& Dwiyanto, 2012) that there is no significant effect of CR, DPR, ROA and $\beta$ (systematic risk) variables to stock price. H2: Earning per share variable also does not significantly affect the stock price. Though, we all know in theory, earning per share is very influential on stock prices. This is because earning per share in pharmaceutical companies for the 4 years that was being studied have decreased in several pharmaceutical sub-sectors. So, this does not affect the interests of investors. The results of this are also in accordance with the results of (Meythi, Kwang En, \& Rusli, 2011) which states that earnings per share doesn't have significant impact on stock price. So is the same with research of (Askar, 2016) that there is no significant effect of earning per share variables to stock price. H3: Price earning ratio variable is found to have no significant effect on stock prices. The results of this are also in accordance with the results of (Yuliyanti, 2014), shows that PER has no significant effect on stock prices. So is the same with research of (Suryadi, 2017), which states that Price Earning Ratio (PER) no significant effect on stock prices. H4: The return on equity variable is found to have a significant effect on stock prices. This is because the profitability of pharmaceutical companies is quite above average so that it attracts investors to invest their capital. Hence, return on equity affects the stock price. The results of this study are also in accordance with the results of (Octavianty \& Aprilia, 2014) which states that the ROE variable significant affect on stock price. So is the same with research of (Darmayanti, 


\section{International Journal of Business Economics (IJBE)}

Vol, 1 Issue 2, pp 102-116, March 2020

http://jurnal.umsu.ac.id/index.php/ijbe

eISSN 2686-472X

2015) that there is significant influence between ROE on stock prices. H5: The variable of return on assets is found to have a significant effect on stock prices. This is because good ROA reflects the use and management of a company's assets optimal so that it will increase profitability and the company's stock price.. The results of this study are also in accordance with the results of (Issah \& Ngmenipuo, 2015) which states that there is a positive linear relationship between ROA, ROE, ROI and the market price of shares of banking financial institutions quoted on the Ghana Stock Exchange (GSE). So is the same with research of (Anwaar, 2016) that there is ROA significant effect on stock return.

\section{CONCLUSION}

For the $\mathrm{F}$ test result (simultaneous test), the researcher found that systematic risk, earnings per share, price earning ratio, return on equity and return on assets simultaneously have a significant effect on stock prices on Pharmaceutical companies listed on the Indonesia Stock Exchange and for the results of t-test (partial test) the researcher found out that the variable of return on equity and return on assets have a significant effect on stock price. For other variables such as systematic risk, earnings per share and price earnings ratio, they do not significantly affect the price of shares listed on the Indonesia Stock Exchange.

\section{REFERENCES}

Abba, M., \& Suleiman, U. (2016). Corporate Attribute and Share Value Of Listed Pharmaceutical Firms In Nigeria. Journal of Arts, Science \& Commerce, VII(1(1)), 8898.

Angela, N. K. (2018). The Analysis of Stock Price in Tourism Industry Listed in Indonesia Stock Exchange 2012-2016 Abstrak. Journal of Applied Accounting and Finance, 2(2), 153-162.

Anwaar, M. (2016). Impact of Firms' Performance on Stock Returns (Evidence from Listed Companies of Ftse-100 Index London, UK). Global Journal of Management and Business Research (D), 16(1), 31-39.

Askar. (2016). Sistem Informasi Akuntansi Berdasarkan EPS, PBV dan ROA terhadap Harga Saham. Jurnal Ekonomi, Manajemen Dan Akuntansi, 6(1), 11-22.

Darmayanti, N. (2015). The Effect of Systematic Risk Model of Fundamental and Stock Company Study Food and Beverage Firm Listing in Indonesia Stock Exchange ( BEI ) Year 2008 - 2012. Research Journal of Finance and Accounting, 6(9), 113-128.

Hatta, A. J., \& Dwiyanto, B. S. (2012). The Company Fundamental Factors and Systematic Risk In Increasing Stock Price. Journal of Economics, Business, and Accountancy Ventura, 15(110), 245-256.

Inyiama, O. I. (2015). Does Earning per Share Determine Market Price of Ordinary Shares? Evidence From Nigeria Banking Sector (2000-2013). European Journal of Accounting Auditing and Finance Research, 3(6), 91-102.

Issah, O., \& Ngmenipuo, I. M. (2015). An Emipiral Study Of The Relationship Between Profitability Rations and Market Share Prices Of Publicly Traded Banking Financial Institutions in Ghana. International Journal of Economics, Commerce and Management, III(12), 27-42.

Kabajeh, M. A. ., Al Nu'aimat, S. M. ., \& Dahmash, F. . (2012). The Relationship between the ROA, ROE and ROI Ratios with Jordanian Insurance Public Companies Market Share Prices. International Journal of Humanities and Social Science, 2(11).

Koluku, R. ., Pengemanan, S. ., \& Tumewu, F. (2015). Analysis Of Market Risk, Financial 


\section{International Journal of Business Economics (IJBE)}

Vol, 1 Issue 2, pp 102-116, March 2020

http://jurnal.umsu.ac.id/index.php/ijbe

eISSN 2686-472X

Leverage and Firm Size Toward Stock Return On Non-Banking Companies Listed in LQ45 Index of IDX. Jurnal Riset Ekonomi, Manajemen, Bisnis Dan Akuntansi, 3(2), 528-536.

Kumar, P. (2017). Impact Of Earning per Share and Price Earning Ratio on Market Price of

Share: A Study on Auto Sector in India. International Journal of ResearchGranthaalayah, 5(2), 113-118.

Menaje, P. M. (2012). Impact of Selected Financial Variables on Share Price of Publicly Listed Firms in the Philippines. American International Journal of Contemporary Research, 2(9), 98-104.

Meythi, Kwang En, T., \& Rusli, L. (2011). The effect of liquidity and profitability on the stock prices of manufacturing companies listed on the Indonesia Stock Exchange. Jurnal Bisnis Manajemen Dan Ekonomi, 10(2).

Mogonta, K., \& Pandowo, M. (2016). Analyzing The Effect Of Return on Assets, Return On Equity and Earning Per Share on Market Share Price: A Study of LQ-45 Mining Companies Listed On Indonesia Stock Exchaneg. Jurnal Riset Ekonomi, Manajemen, Bisnis Dan Akuntansi, 4(2), 703-713.

Musyoki, D. (2012). Changes in share prices as a predictor of accounting earnings for financial firms listed in Nairobi Securities Exchange. International Journal of Buniess and Public Management, 2(21), 1-11.

Octavianty, E., \& Aprilia, F. (2014). Pengaruh Earning per Share ( EPS), Book Value per Share (BVS), Return on Equity (ROE), dan Debt to Equity Ratio (DER) terhadap Harga Saham Perusahaan BUMN yang Terdaftar di BEI. Jurnal Ilmiah Manajemen Fakultas Ekonomi, Semester I, 7-15.

Pasaribu, R., \& Gunadarma, U. (2008). Pengaruh Variabel Fundamental Terhadap Harga Saham Perusahaan Publik Di Bursa Efek Indonesia. Jurnal Ekonomi Dan Bisnis, 2(2), 101-113.

Robbetze, N., Villiers, R. De, \& Harmse, L. (2017). The Effect Of Earnings Per Share Categories On Share Price Behaviour: Some South African Evidence. The Journal of Applied Busniess Research, 33(1), 141-152.

Sukhija, M. S. (2014). Fundamental Determinants affecting Equity Share Prices of BSE- 200 Companies in India. European Journal of Business and Management, 6(31), 160-171.

Sulistyowati, Y. (2011). Pengaruh Earning Per Share ( EPS ), Price Earning Ratio ( PER ), dan Dividend Payout Ratio ( DPR ) terhadap Harga Saham ( Studi Empiris Pada Perusahaan Food \& Beverages Yang Terdaftar di BEI ). Jurnal Ekonomi Modernisasi, 247-255.

Suryadi, H. (2017). Analisis Pengaruh ROI, DTA, QR, TATO, PER pada Harga Saham Perusahaan Batubara di BEI. Jurnal Ilmiah Ekonomi Bisnis, 3(1), 16-23.

Talamati, M. R., \& Pangemanan, S. S. (2014). The Effect Of Earnings per Share (EPS) \& Return on Equity (ROE) On Stock Price Of Banking Company Listed In Indonesia Stock Exchange (IDX) 2010-2014. Jurnal Riset Ekonomi, Manajemen, Bisnis Dan Akuntansi, 3(2), 2010-2014.

Tamuntuan, U. (2015). Analysing The Effect Of Return On Equity, Return On Assets and Earnings Per Share Toward Share Price: An Emperical Study of Food and Beverage Companies Listed On Indonesia Stock Exchange. Jurnal Berkala Ilmiah Efisiensi, 15(05), 446-457.

Vora, K. (2018). Influence of Financial Performance Indicators on Market Price of Shares of Nifty 50 Companies. International Journal of Advance Research in Computer Science 


\section{International Journal of Business Economics (IJBE)}

Vol, 1 Issue 2, pp 102-116, March 2020

http://jurnal.umsu.ac.id/index.php/ijbe

eISSN 2686-472X

and Management Studies, 6(2), 67-75.

Yuliyanti, L. (2014). Pengaruh Kinerja Perusahaan Terhadap Harga Saham Perusahaan

Automotif and Component di Bursa Efek Indonesia. Jurnal Dinamika Akuntansi Dan Bisnis, 1(1), 1-11.

www.finance.com

www.idx.co.id 